\title{
Glutamine and its effects on the intestine
}

\author{
Paul E Hardy, MD, Richard N Fedorak, MD, FRCPC, Alan BR THOMSON, MD, PHD, FRCPC, FACP, \\ Olin G THURSTON, MD, FRCSC, FA
}

\begin{abstract}
PE HARDY, RN FEDORAK, ABR THOMSON, OG THURSTON. Glutamine and its effects on the intestine. Can J Gastroenterol 1991;5(3):94-102. Glutamine, an amino acid, is the principal energy substrate for small intestinal cells. It also acts as a nitrogen carrier through its amide nitrogen. Arterial glutamine is supported by net synthesis in skeletal muscle. Glutamine is rapidly metabolized by the intestine, whether supplied from the lumen or from the arterial circulation. Intestinal uptake of glutamine increases after trauma and operative stress. The consumption of glutamine by the gut may in large part be dependent on mucosal glutaminase activity and on enterocyte glutamine transport. Glutamine has been shown to improve gut morphology and outcome in anin.al models of enterocolitis. It may play a similar role in aiding repair of human intestinal injury in persons with sufficient glutamine in their diet compared to those who are glutamine deficient. Glutamine may have a positive effect on the immune function of the intestinal mucosal-associated lymphoid tissue. Glutamine is not currently available in nutritional preparations for routine clinical use, yet it has recently been shown to benefit maintenance of nitrogen balance in humans. Due to the instability and low solubility of glutamine, dipeptides have been studied. L-alanyl-L-glutamine seems to be the most promising glutamine precursor for parenteral use in humans, as it is safe and rapidly hydrolyzed in vivo to release free glutamine. The exact role of glutamine as a therapeutic agent to promote intestinal well-being has yet to be determined. However, preliminary evidence suggests that glutamine will be helpful in a variety of clinical scenarios.
\end{abstract}

Key Words: Amino acid, Glutamine, Nutrition, Small intestine

\section{La glutamine et son action sur l'intestin}

RESUME: La glutamine est un acide aminé qui est le substrat énergétique principal des cellules de l'intestin grêle. Elle agit aussi à titre de transporteur d'azote par l'azote aminé. La glutamine artérielle est soutenue par synthèse nette au niveau des muscles squelettiques. Qu'elle provienne de la lumière ou de la circulation artérielle, la glutamine est rapidement métabolisée par l'intestin. La capture de glutamine par l'intestin augmente après une lésion ou le stress opératoire. La consommation de glutamine par l'intestin pourrait en grande

Departments of Surgery and Gastroenterology, University of Alberta, Edmonton, Alberta Correspondence and reprints: Dr ABR Thomson, 519 Robert Newton Research Building, University of Alberta, Edmonton, Alberta T6G 2C2. Telephone (403) 492-6490, Fax (403) $492-7964$

Received for publication April 2, 1991. Accepted May 10, 1991
$T$ HE AMINO ACID GLUTAMINE HAS become a subject of great interest in recent years because of its vital role in intestinal metabolism. Glutamine has been shown to reduce the effects of enterocolitis in experimental animal models $(1-8)$. Due to its low stability in aqueous solution and relative insolubility, glutamine is not readily available in commercial enteral or parentera nutrition solution preparations. This paradox of apparent need yet unavail ability of glutamine is the impetus to the present review of glutamine and its effects on healing of intestinal injury.

\section{BIOCHEMISTRY}

Glutamine is detected in large quan. tities in many animal tissues. In addi. tion to being a protein constituent, glutamine has several other functions $(9-11)$. Glutamine's classification as a nonessential amino acid may be mis. leading (12) in view of its diverse and important roles $(10,11)$, especially in the intestinal tract (13-18). The degradation of glutamine to glutamate by glutaminase (Figure 1) has been studied in numerous tissues $(19,20)$, and the properties of the enzyme have been reviewed $(9,21)$. Glutamine is an energy source via the Kreb's cycle, and a nitrogen donor for the urea cycle and for nucleotide synthesis. The metabolism of glutamine by the intestine has been comprehensively reviewed by Windmueller $(20,22,23)$ and others $(13-16)$. Energy production from 
partie dépendre de l'action de la glutaminase présente dans la muqueuse, et du transport de la glutamine par les entérocytes. Il est prouvé que la glutamine améliore la morphologie de l'intestin et l'évolution de l'entérocolite chez les modèles animaux. Elle pourrait jouer un rôle similaire en contribuant à la guérison des lésions intestinales chez les patients dont le régime alimentaire contient suffisamment de glutamine par rapport à ceux qui souffrent de carences. La glutamine aurait une action positive sur la fonction immunitaire du tissu lymphoide associé à la muqueuse intestinale. Pour le moment, la glutamine ne fait pas partie des préparations nutritionnelles d'usage clinique courant; on a pourtant récemment établi qu'elle contribuait à maintenir un bilan azoté équilibré chez l'homme. A cause de l'instabilité et de la faible solubilité de la glutamine, on s'est penché sur les dipeptides. La L-alany L-L-glutamine semble le précurseur le plus prometteur de la glutamine pour l'utilisation parentérale chez I'homme: elle est sûre et rapidement hydrolysée in vivo pour libérer la glutamine libre. Le rôle exact de la glutamine en tant qu'agent thérapeutique favorisant la santé de l'intestin reste encore à déterminer. Toutefois, les résultats préliminaires laissent entrevoir l'utilité de la glutamine dans divers tableaux cliniques.

glutamine has been demonstrated in the intestine (24-26), lymphocytes (27), fibroblasts (28) and malignant cells $(29,30)$.

\section{INTERORGAN RELATIONSHIPS}

Glutamine balance across various organs has been well documented (31. 33). Glutamine synthesis occurs in the muscle of healthy individuals (34-36) and in the lungs of septic patients $(15,37,38)$. The intestine is normally a glutamine consumer (39), as is the kidney during acidosis $(31,40)$. Excretion of urinary ammonia is a reflection of the kidney's tendency to consume glutamine in the acidotic state. The liver has a complex relationship with glutamine metabolism; on average it is in glutamine balance. The liver synthesizes glutamine to detoxify portal ammonia (41-44) and may consume glutamine under other circumstances (Figure 2).

\section{GLUTAMINE AND THE INTESTINE: EXPERIMENTAL ASPECTS}

Intestinal energy substrates: In 1965 , Neptune (25) reported that glutamine was oxidized in preference to glucose in rabbit ileum. More detailed work on glutamine as an intestinal energy substrate was done in the 1970 s by Windmueller and Spaeth $(24,26,45)$ and others (46-49). The contribution of glutamine to respiratory carbon dioxide in the intestine is high (50), indicating strates (52). These nutrients are primarily derived in vivo from fermentation of luminal contents by endogenous microflora. The small intestine prefers glutamine for fuel, whereas the colon shows a preference for short chain fatty acids and ketone bodies (53-58). Human colonocytes preferentially metabolized short chain fatty acids over glutamine, especially those sampled from the distal colon (59). Glutamine metabolism was higher in proximal versus distal colonocytes.

\section{CONSUMPTION}

Windmueller and Spaeth (24) used isolated, vascularly perfused rat intestine to investigate the metabolic fate of glutamine and demonstrated the relative importance of the small bowel in glutamine metabolism. They then studied the in vivo metabolism of glutamine in a luminally perfused segment of rat intestine (45). Labelled carbon dioxide accounted for $60 \%$ of

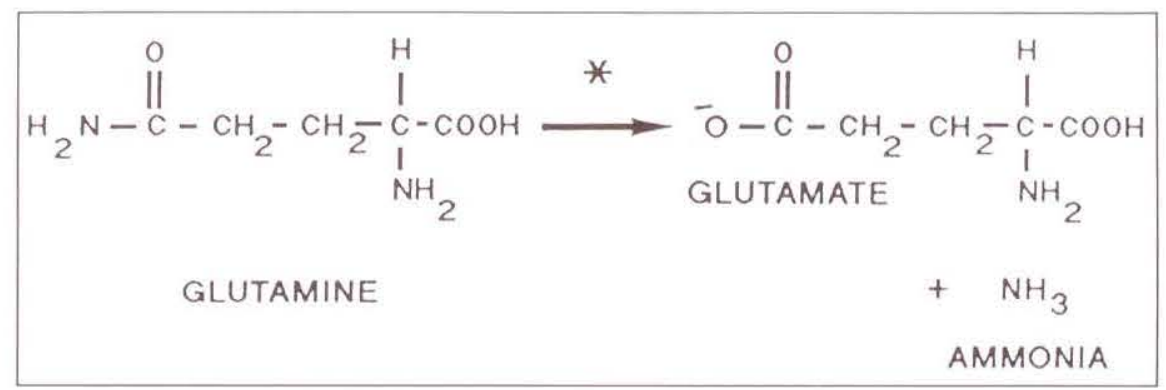

Figure 1) The enzymatic degradation of glutamine to glutamate and ammonia, *Glutaminase

INTERORGAN RELATIONSHIPS

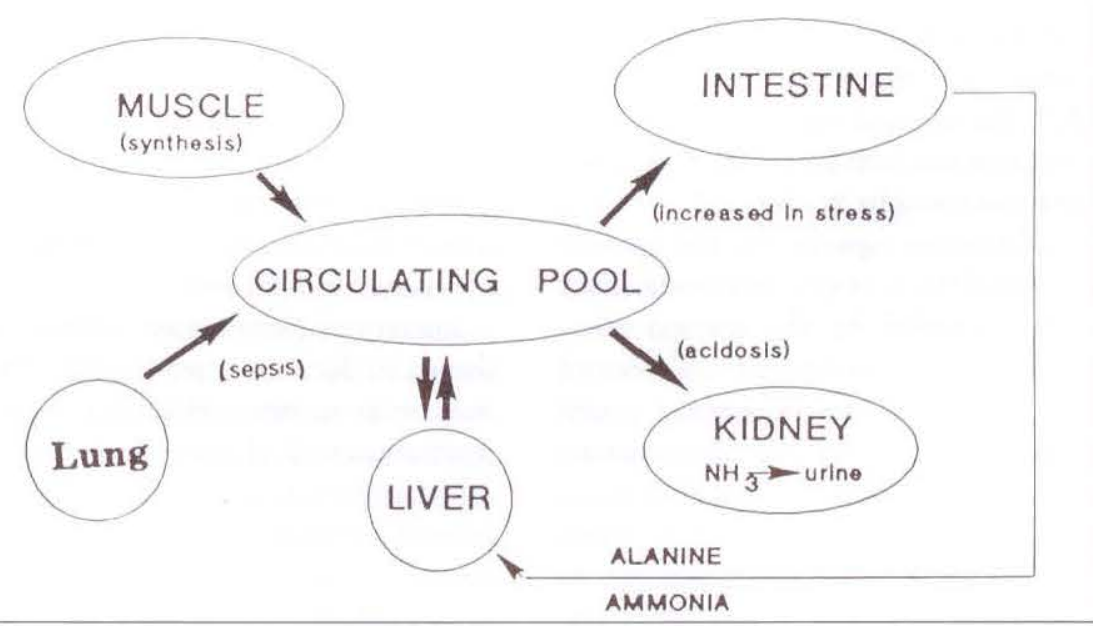

Figure 2) Interorgan relationships of glutamine. Bold arrows indicate predominant direction of glutamine transfer. (Adapted from reference 14) 
the glutamine carbon recovered. The metabolic products recovered with respect to both glutamine nitrogen and carbon showed a profile strikingly similar to those of vascularly perfused segments. These results suggest that there is a common glutamine pool within mucosal cells consisting of both luminally and arterially derived glutamine. The experiments achieved similar results using germ-free rats, indicating that intestinal microflora were not responsible for the breakdown of luminal glutamine and ammonia release. No ${ }^{14} \mathrm{C}$-glutamate was released in venous blood after glutamine luminal perfusion, indicating that the rate-limiting step in intestinal glutamine metabolism is the deamidation of glutamine to glutamate.

Weber and Veach $(60,61)$ studied ammonia production in the intestines of dogs. The small intestine was comparable to the uncleansed colon in terms of amount of ammonia released into portal blood. Ammonia from the small intestine was nearly fully accounted for by the breakdown of glutamine. In contrast, $51 \%$ of the ammonia released by the colon was due to metabolism of glutamine and urea; the remaining portion was presumably produced by intestinal flora. Glucose was infused to determine if an energy source alternate to glutamine would reduce the amount of ammonia released in portal blood. Instead, luminal infusion of glucose significantly increased mesenteric venous ammonia release and intestinal glutamine consumption. Hepatic synthesis of glutamine helps detoxify ammonia (42); the clinical implications of ammonia production and glutamine have been discussed by Souba (33).

Glutamine uptake by the gastrointestinal tracts of splenectomized dogs nearly doubled by the second postoperative day compared to control animals in the face of reduced portal bloodflow and lower arterial glutamine levels (62). Glutamine consumption is probably up-regulated rather than determined solely by the quantity of glutamine presented to the gut. Conversely, rat intestinal glutamine extraction is decreased in sepsis $(63,64)$ and diabetes (65) and soon after massive small bowel resection (66). Glutamine extraction in the small intestine of peak lactating rats was increased compared to nonlactating controls (67). Glutamine consumption was increased in vivo and in isolated enterocytes after rats were treated with dexamethasone (68). Similarly, gut glutamine uptake doubled in dogs receiving anabolic steroids compared to controls (69).

Glutaminase: Glutamine is used by the intestine whether supplied arterially or luminally. The metabolic fate of glutamine is similar for both modes of entry into the mucosal cell. Intestinal glutamine extraction is modified by many factors, probably through modulation of the rate-limiting step of glutamine metabolism: deamidation by enterocyte glutaminase. High enzyme levels are found in the bowel mucosa of several species including rat, dog, hamster and monkey (20) but not guinea pigs or chickens (20). Lower blood glutamine levels and intestinal extraction were noted in the latter two species. Intestinal glutaminase is predominantly the phosphate-dependent type (20) and is located in the mitochondria of mucosal epithelial cells. Intestinal glutaminase has a high substrate affinity consistent with low mucosal cell concentrations of glutamine. Phosphate-independent glutaminase and other enzymes required for glutamine metabolism showed low activity.

It has been postulated that stimulation of intestinal glutaminase activity may be necessary for the gut to take full advantage of circulating glutamine (8). The well-being of the intestine may therefore depend on both the supply of glutamine and the activity of glutaminase. Glutaminase activity is affected by a number of factors.

Intestinal glutaminase activity was shown to decrease after 48 and $72 \mathrm{~h}$ of starvation in rats $(54,70,71)$. Supplementation with glutamine (20) did not raise intestinal mucosal glutaminase activity compared to controls unless a period of prior fasting was employed (72). Dexamethasone increased glutaminase-specific activity in both jejunum and colon of rats two days after administration (73). The enzyme was unaffected by acidosis $(20,70,74)$ or potassium deficiency (70). Another study showed a decrease in small intes. tinal glutaminase in chemically induced acidosis (75), with no change in the colonic enzyme. The effect of acidosis on intestinal glutaminase is clearly different from that on kidney glutaminase, where acidosis up-regulates renal glutaminase in order to promote urinary ammonia excretion (20). Septic rats have demonstrated decreased consumption of glutamine along with reduced glutaminase activity in small intestinal mucosal scrapings (64).

Streptozotocin-diabetic rats showed decreased glutaminase activity in both colonic mucosal scrapings and the whole colon (75). A substantial in. crease was observed in small intestinal glutaminase activity for the whole organ but not for mucosal scrapings $(74,75)$. The increased enzyme activity paralleled the increase in intestine size which normally accompanies induced diabetes in rats. The higher total enzyme activity was accompanied by complete suppression of glutamine extraction measured by arteriovenous differences (74). This example in diabetic rats is an exception to the hypothesis that glutamine consumption is predom. inantly a function of glutaminase ac tivity.

Glutamine transport: Brush border membrane glutamine transport occurs by two mechanisms $(76,77)$. The primary route is via a sodium-dependent system. Glutamine is also transported by a sodium-independent, carriermediated system. Both are saturable and inhibited by other amino acids. Glutamine transport occurred against a chemical gradient, evidenced by an 'overshoot' phenomenon prior to equilibration. Similar glutamine transport was documented in human brush border membrane vesicles (78). Brush border membrane transport of glutamine was increased in diabetic rats (79). This finding contrasts with decreased en. dogenous glutamine intestinal cell up. take (80), implying that in diabetes the enterocyte favours dietary rather than endogenous glutamine. This effect was reversed by insulin. Dietary glutamine 
supplementation for four days after an equal period of fasting in rats resulted in a $75 \%$ increase in glutamine brush border membrane uptake over controls (76). The clinical relevance of enhanced intestinal glutamine transport is not yet clear, although it has been speculated that an impact on gut metabolism, structure and function may play a role (76).

Basolateral intestinal membrane transport of glutamine (which would occur from arterial blood during fasting) has also been characterized in rats (81-83). Glutamine transport was carrier-mediated and probably involved an exchange of extracellular glutamine for intracellular alanine. Alanine, a metabolite of glutamine (22), is a logical substance to exchange: as a nonenergy byproduct of glutamine metabolism, it becomes available to the liver for gluconeogenesis as more glutamine enters the enterocyte for processing. Similar transport systems were reported for rat colonocytes (84) and human small intestinal basolateral membrane vesicles (85).

Intestinal injury models and glutamine: Baskerville (86) administered parenteral glutaminase to monkeys and other mammals in order to investigate its properties as an antitumour agent. All but the lowest doses were fatal within 10 days. All animals had vomiting, dysentery and diarrhea. Pathological features included lesions in liver, kidney and intestine, the most prominent being an acute necrotizing colitis. The colonic lesions were histologically similar to human ulcerative colitis, and a suggested mechanism is that of glutamine deficiency induced by the glutaminase enzyme (86).

Healthy rats (87) receiving parenteral nutrition had increased jejunal mucosal weight, DNA content and villus height when glutamine was added to the solution. Recovery including weight gain and intestinal adaptation after $60 \%$ bowel resection in rats was enhanced (88). Rats with intraperitoneal 5-fluorouracil-induced enterocolitis were given total parenteral nutrition with or without glutamine (1). After four days, the glutamine-supplemented rats had increased small bowel mucosal
DNA content and villus height. There was a trend towards increased survival in glutamine-fed rats. Methotrexateinduced enterocolitis in glutaminetreated rats has also been studied $(4,5)$. In these experiments, an enteral diet was supplemented with glutamine for the treatment group and with glycine for controls. A four day period of prefeeding was employed. Groups treated with glutamine had less protein and DNA loss in the colon and jejunum. Animals fed supplemental glutamine had improved survival curves and a significantly lower incidence of positive blood cultures.

Glutamine has also been shown to be beneficial in radiation enteritis models in rats $(6-8)$. Bacterial translocation, indicated by culture positive mesenteric lymph nodes (7) and bloody diarrhea (8) was significantly decreased in the glutamine-fed irradiated group. Mucosal mass was maintained and weight loss less with glutamine treatment. Reasons postulated include protection of the gut mucosal barrier by glutamine as an energy substrate and as a nitrogen donor for nucleotide synthesis. Glutamine may also have enhanced lymphocyte function to decrease bacterial translocation. Arterial glutamine levels, intestinal glutamine extraction and intestinal glutaminase levels were all higher in the glutamine-fed irradiated animals. Arterial glutamine levels $(2,7,8)$ and extraction (8) are significantly increased only when dietary supplementation is combined with intestinal injury. Glutaminase levels, however, have increased with dietary glutamine alone after an initial period of fasting (72). Glutaminase may help the animal to take advantage of circulating glutamine from endogenous sources (8).

Of the injury models discussed (5. fluorouracil, methotrexate and radiation), glutamine was administered through the gastrointestinal tract in all but one study (1). Most experiments had a period of prefeeding of glutamine prior to injury induction. The injury models examined glutamine's effect on intestinal morphometrics predominantly, although bacterial translocation $(5-7)$ and survival $(1,5,8)$ were also considered. While these findings cannot be extrapolated to humans directly, they are suggestive of many possible clinical applications (89), and potentially demonstrate glutamine's role in supporting gut mucosal structure and function.

\section{GLUTAMINE AND THE INTESTINE: CLINICAL ASPECTS}

Starvation: Significant alterations of glutamine metabolism occur during starvation (90-92). During the post absorptive state or early fasting, the intestine obtains most of its glutamine from the arterial blood. After four days, the intestine increased its uptake of glutamine from the circulation by $80 \%$. This increase was accompanied by the liver switching to glutamine release. Intestinal uptake of glutamine is increased in starvation despite lower mucosal glutaminase levels and is therefore likely a reflection of increased supply from other endogenous sources. Surgical trauma: Trauma and surgical stress result in nitrogen loss due to muscle catabolism. Elective cholecystectomy in man results in decreased plasma amino acid levels, including glutamine, in the early postoperative period (93). The negative nitrogen balance associated with surgery was significantly reduced in six patients receiving a glutamine-containing parenteral fluid undergoing elective resection of colonic carcinoma compared to controls (94). A similar benefit to postoperative nitrogen balance has been observed as a result of intravenous infusion of glutamine in humans $(95,96)$. The gut uses substantially more glutamine after operative stress (18); this is probably partially mediated through glucocorticoids $(97,98)$ and glucagon (99).

Souba et al (100) studied the effects of enterectomy on glutamine interorgan exchange in dogs. After $60 \%$ small bowel resection, the intestine entered near glutamine balance, compared to avid glutamine consumption in controls. Alanine was released from the intestine at a significantly lower rate in the resection group. The intestine uses glutamine in the postopera- 
tive state, reflected by reduced total intestinal glutamine consumption in partially resected animals.

Alanine and glutamine are released from muscle in large quantities in healthy (34) and critically ill (101) patients. Alanine and glutamine were studied in healthy volunteers and critically ill patients who underwent laparotomy (101). These amino acids were significantly decreased in arterial blood in the patient groups. Two patients who underwent greater than $80 \%$ bowel resection had a markedly decreased extremity glutamine efflux. Both healthy volunteers and those who underwent laparotomy without enterectomy had normal glutamine mobilization. Thus, surgical stress resulting in catabolism and negative nitrogen balance is characterized by increased intestinal uptake of glutamine. Alanine and ammonia, released in portal blood, are converted to glucose and urea by the liver. Muscle provides glutamine to the gut; however, if no exogenous glutamine is available to the stressed patient, the circulating pool becomes depleted.

Sepsis: As with trauma, the septic patient displays increased mobilization of glutamine with an associated negative nitrogen balance. However, in sepsis, intestinal consumption of glutamine is decreased in both rats and humans $(63,64)$. At the expense of intestinal uptake, both lymphocyte and hepatic consumption of glutamine increase (102). Additional glutamine is supplied to the circulating pool by the lungs (37).

A detailed study of a multiple trauma patient revealed a steady decrease in splanchnic uptake of both glutamine and alanine over time (103. 105). Both alanine and glutamine uptake reached zero as the patient became systemically septic and began deteriorating on day 10 . Although this observation does not distinguish between intestinal and hepatic consumption, the patient's poor condition was likely coincidental with decreased intestinal consumption of glutamine (for gut energy substrate) and reduced hepatic uptake of alanine (for gluconeogenesis). In the basal state, glutamine is used by the intestine as an energy substrate.

Malignancy: Glutamine is the principal amino acid consumed by malignant cells $(29,30)$; therefore consideration must be paid to both the tumour and the intestine in the cancer patient. That tumour cells may compete with the intestine for use of the circulating glutamine pool was suggested by an experiment using tumour-bearing rats (106). Glutamine's benefit to the intestine in the radiation enteritis model (6-8) may also benefit a malignant tumour treated by radiation. Therefore, indiscriminate administration of glutamine as an intestinal protectant to a patient with a malignancy would not be prudent. Glutamine has been shown to support muscle without stimulating tumour growth in rats (107). It afforded more benefit to the intestine than to lymphocytes with 5-fluorouracil toxicity (1). Until a better understanding of glutamine's role in malignant disease is obtained, caution regarding glutamine supplementation is urged (108). Glutamine and nutritional preparations: Changes in the gastrointestinal tract that occur as a result of parenteral feeding include mucosal hypoplasia, decreased carbohydrate transport and reduced enzyme activities $(109,110)$. These changes do not occur with enteral feeding. It is suggested that enteral glutamine is especially important in maintaining healthy intestinal mucosa $(110,111)$. For example, glutamine supplementation of an elemental enteral diet for rats resulted in increased jejunal mass and crypt mitotic rate over controls (112). Glutamine and fibre were added to diets of separate groups of rats and neither reduced bacterial translocation, although benefits to jejunal mucosal architecture were noted (113).

Glutamine is not presently available in total parenteral nutrition solution due to its low solubility, instability and potential release of toxic products (ammonia and glutamate). Parenteral nutrition supplemented with glutamine resulted in increased jejunal weight, protein, DNA, mucosal thickness and villus height in rats $(87,114)$. A similar benefit was demonstrated in colon and stomach with enhanced jejunal disac- charidase activity (115).

It has been suggested that glutamine may be beneficial to the immune system through support of gut-associated lymphatic tissue (116). Supplementation of total parenteral nutrition with glutamine significantly reduced positive bacterial cultures of mesenteric nodes in rats (117). This phenomenon may have been due to improved im. mune function as secretory $\operatorname{IgA}$ levels in bile were observed to be significantly higher than in rats receiving glutamine-deficient total parenteral nutrition. The beneficial effects of parenteral glutamine on intestinal mor. phology were enhanced by the addition of epidermal growth factor (118), sup. porting the general hypothesis that specific nutrients in combination with hormonal factors can provide maximal growth of tissue.

The safety of intravenous glutamine has been studied in healthy volunteers $(119,120)$. There were no untoward side effects noted, nor signs of central nervous system toxicity. Plasma levels of ammonia and glutamate (two potential toxic metabolites of glutamine) were not significantly elevated. Amino acid levels, cortisol, insulin, glucagon, growth hormone values and routine chemistry analyses were all unchanged. Intravenous glutamine did increase in. sulin levels slightly in another study (121). There was a significantly higher rise in arterial glutamine from intravenous compared to oral glutamine, suggesting splanchnic uptake of glutamine in the orally administered group. Glutamine has also been given in an intravenous parenteral solution over four weeks to patients receiving bone marrow transplants (120). This was well tolerated with no untoward effects.

The use of dipeptides with glutamine and an additional amino acid has been considered (122). Three dipeptides containing glutamine were compared in conscious dogs (123). Alanyl and glycyl glutamine dipeptides were hydrolyzed in vivo rapidly, resulting in prompt elevation of arterial glutamine. In humans, L-alanyl-L-glutamine was hydrolyzed more rapidly than L-glycylL-glutamine (124). The mechanism suggested reflects both plasma and 
extracellular cell membrane hydrolysis. Intravenous use of $\mathrm{N}$-acetyl-L-glutamine was studied in 14 healthy humans (125); however, the kinetics of consumption of this dipeptide render it less than ideal for clinical use.

Clinical applications of glutamine dipeptides have been reviewed (126, 127). L-alanyl-L-glutamine seems to be the most practical glutamine precursor for use in humans. Its properties have been studied in dogs (128), rats (129) and humans (130). L-alanyl-L-gluta-

\section{REFERENCES}

1. O'Dwyer ST, Scott T, Smith RJ, Wilmore DW. 5-Fluorouracil toxicity on small intestine but not white blood cells is decreased by glutamine. Clin Res 1987;35:369A.

2. Jacobs DO, Evans AE, O'Dwyer ST, Smith RJ, Wilmore DW. Disparate effects of 5 -fluorouracil on the ileum and colon of enterally fed rats with protection by dietary glutamine. Surg Forum 1987;38:45-7.

3. Fox AD, Kripke SA, Berman JM, Settle RG, Rombeau JL. The effect of glutamine supplemented enteral nutrition on methotrexate induced enteritis. Am J Clin Nutr 1987;45:850.

4. Fox AD, Kripke SA, Berman JM, Settle RG, Rombeau JL. Reduction of the severity of enterocolitis by glutamine-supplemented enteral diets. Surg Forum 1987;38:43-4.

5. Fox AD, Kripke SA, De Paula J, Berman JM, Settle RG, Rombeau JL. Effect of a glutamine-supplemented enteral diet on methotrexate-induced enterocolitis. JPEN 1988;12:325-31.

6. Klimberg VS, Souba WW, Dolson DJ, et al. Prophylactic glutamine protects the intestinal mucosa from radiation injury. Cancer 1990;66:62-8.

7. Souba WW, Klimberg VS, Hautamaki RD, et al. Oral glutamine reduces bacterial translocation following abdominal radiation. J Surg Res 1990;48:1-5.

8. Klimberg VS, Salloum RM, Kasper M, et al. Oral glutamine accelerates healing of the small intestine and improves outcome after whole abdominal radiation. Arch Surg 1990;125:1040-5.

9. Kovacevic Z, McGivan JD. Mitochondrial metabolism of glutamine and glutamate and its physiological significance. Physiol Rev 1983;63:547-605.

10. Bulus N, Cersosimo E, Ghishan F, Abumrad NN. Physiologic importance of glutamine. Metabolism 1989;38(Suppl 1):1-5. mine is 16 times more soluble than glutamine alone and is stable under conditions of heat sterilization and storage (131). No side effects were noted in clinical trials (131), and the benefits of L-alanyl-L-glutamine have been noted in catabolic patients $(94,132)$. Glutamine dipeptides have been given intravenously to septic patients with no impairment of peptide metabolism (122); however, more study is required if they are to be used in patients with either hepatic or renal failure.

11. Smith RJ. Glutamine metabolism and its physiologic importance. JPEN 1990; 14:40S-4S.

12. O'Dwyer ST, Smith RJ, Huang TL, et al. Glutamine: An essential nonessential amino acid for the gut. Gastroenterology 1990;99:279-81.

13. Hartmann F, Plauth M. Intestinal glutamine metabolism. Metabolism 1989;38(Suppl 1):18-24.

14. Klimberg VS, Souba WW. The importance of intestinal glutamine in maintaining a healthy gastrointestinal tract and supporting the body's response to injury and illness. Surg Annu 1990;22:61-76.

15. Souba WW, Klimberg VS, Plumley $\mathrm{DA}$, et al. The role of glutamine in maintaining a healthy gut and supporting the metabolic response to injury and infection. J Surg Res 1990;48:383-91.

16. Page CP. The surgeon and gut maintenance. Am J Surg 1989;158:485-90.

17. Souba WW, Hersowitz K, Austgen TR, et al. Glutamine nutrition: Theoretical considerations and therapeutic impact. JPEN 1990;14(Suppl):237S-43S.

18. Souba WW, Herskowitz K, Salloum RM, et al. Gut glutamine metabolism. JPEN 1990;14:45S-50S.

19. Krebs HA. The synthesis of glutamine from glutamic acid and ammonia, and the enzymic hydrolysis of glutamine in animal tissues. Biochem J 1935;29:1951-69.

20. Pinkus LM, Windmueller HG. Phosphate-dependent glutaminase of small intestine: Localization and role in intestinal glutamine metabolism. Arch Biochem Biophys 1977;182:506-17.

21. Meister A. Enzymology of glutamine. In: Haussinger D, Sies H, eds. Glutamine Metabolism in Mammalian Tissues. Berlin: Springer-Verlag, 1984:3-15.

22. Windmueller HG. Glutamine consumption by the small intestine.

\section{CONCLUSIONS}

Glutamine is an amino acid whose importance in clinical medicine is rapidly being elucidated. As glutamine is important to rapidly dividing cells, the intestine has been of central interest. Glutamine will likely benefit critically ill subjects, as it is these patients whose endogenous sources cannot meet increased demands during stress. The introduction of glutamine dipeptides in parenteral nutrition solutions will likely be clinically important.

Adv Enzymol 1982;53:201-37.

23. Windmueller HG. Enterohepatic aspects of glutamine metabolism. In: Mora J, Palacios R, eds. Glutamine: Metabolism, Enzymology and Regulation. New York: Academic Press, 1980:235-57.

24. Windmueller HG, Spaeth AF. Uptake and metabolism of plasma glutamine by the small intestine. J Biol Chem 1974:249:5070-9.

25. Neptune EM Jr. Respiration and oxidation of various substrates by ileum in vitro. Am J Physiol 1965;209:329-32.

26. Windmueller $\mathrm{HG}$, Spaeth $\mathrm{AE}$. Respiratory fuels and nitrogen metabolism in vivo in small intestine. J Biol Chem 1980;255:107-12.

27. Ardawi MSM, Newsholme EA. Maximum activities of some enzymes of glycolysis, the tricarboxylic acid cycle and ketone-body and glutamine consumption pathways in lymphocytes of the rat. Biochem J 1982;308:743-8.

28. Donnelly M, Schemer IE. Energy metabolism in respiration-deficient and wild type Chinese hamster fibroblasts in culture. J Cell Physiol 1976;89:39.52.

29. Kovacevic Z, Morris HP. The role of glutamine in the oxidative metabolism of malignant cells. Cancer Res 1972;32:326-33.

30. Coles NW, Johnstone RN. Glutamine metabolism in Erlich acites carcinoma cells. Biochem J 1961;83:284.

31. Schrock H, Goldstein L. Interorgan relationships for glutamine metabolism in normal and acidotic rats. Am J Physiol 1981;240:E519-25.

32. Wilmore DW, Smith RM, O'Dwyer ST, Jacobs DO, Ziegler TR, Wang X-D. The gut: A central organ after surgical stress. Surgery 1988;104:917-23.

33. Souba WW. Interorgan ammonia metabolism in health and disease: $\mathrm{A}$ surgeon's view. JPEN 1987;11:569-79.

34. Ruderman NB, Berger $M$. The formation of glutamine and alanine in 
skeletal muscle. I Biol Chem 1974;249:5500-6.

35. Garber AJ. Glutamine metabolism in skeletal muscle. In: Mora J, Palacios R, eds. Glutamine: Metabolism,

Enzymology and regulation. New York: Academic Press, 1980:259-84.

36. Abumrad NN, Rabin D, W ise KL, Lacey WW. The disposal of intravenously administered amino acid load across the human forearm. Metabolism 1982;31:463-70.

37. Plumley DA, Souba WW, Hautamaki RD, et al. Accelerated lung amino acid release in hyperdynamic septic surgical patients. Arch Surg 1990;125:57-61

38. Souba WW, Herskowitz K, Plumley DA. Lung glutamine metabolism. JPEN 1990;14:68S-70S.

39. Souba WW, Smith RJ, Wilmore DW. Glutamine metabolism by the intestinal tract. JPEN 1985;9:608-17.

40. Addae SK, Lotspeich WD. Relation between glutamine consumption and production in metabolic acidosis. Am J Physiol 1968;215:269-77.

41. Haussinger D. Glutamine metabolism in the liver: Overview and current concepts. Metabolism 1989;38:14-7.

42. Sies H, Haussinger D. Hepatic glutamine and ammonia metabolism. In: Haussinger $\mathrm{D}$, Sies $\mathrm{H}$, eds. Glutamine Metabolism in Mammalian Tissues Berlin: Springer-Verlag, 1984:78-97.

43. Haussinger D. Liver glutamine metabolism. JPEN 1990;14:56S-62S

44. Cersosimo E, Williams P, Geer R, Lairmore T, Ghishan F, Abumrad NN. Importance of ammonium ions in regulating hepatic glutamine synthesis during fasting. Am J Physiol 1989;257:E514-9.

45. Windmueller HG, Spaeth AE. Intestinal metabolism of glutamine and glutamate from the lumen as compared to glutamine from the blood. Arch Biochem Biophys 1975;171:662-72.

46. Hanson PJ, Parsons DS. Glutamine and glucose as fuels for the fed, fasted and acidotic rat small intestine. J Physiol (Lond) 1977;268:13P-4P.

47. Hanson PJ, Parsons DS. Metabolism and transport of glutamine and glucose in vascularly perfused small intestine rat. Biochem J 1977;166:509-19.

48. Aikawa T, Matsutaka H, Yamamoto $\mathrm{H}$, et al. Gluconeogenesis and amino acid metabolism II. Interorganal relations and roles of glutamine and alanine in the amino metabolism of fasted rats. Biochem J 1973;74:1003-19.

49. Matsutaka H, Aikawa T, Yamamoto $\mathrm{H}$, Ishikawa E. Gluconeogenesis and amino acid metabolism III. Uptake of glutamine and output of alanine and ammonia by non-hepatic splanchnic organs of fasted rats and their metabolic significance. J Biochem 1973;74:1019-29.

50. Windmueller HG. Metabolism of vascular and luminal glutamine by intestinal mucosa in vivo. In: Haussinger D, Sies H, eds. Glutamine Metabolism in Mammalian Tissues. Berlin: Springer-Verlag, 1984:62-77.

51. Windmueller HG, Spaeth AE Identification of ketone bodies and glutamine as the major respiratory fuels in vivo for post absorptive rat small intestine. J Biol Chem 1978;253:69-76.

52. Roediger WEW. Utilization of nutrients by isolated epithelial cells of the rat colon. Gastroenterology 1982;83:424-9.

53. Marliss EB, Aoki TT, Pozefsky T, Most AS, Cahill GF Jr. Muscle and splanchnic glutamine and glutamate metabolism in postabsorptive and starved man. J Clin Invest 1971;50:814-7.

54. Ardawi SM, Newsholme EA. Fuel consumption in colonocytes of the rat. Biochem J 1985;231:713-9.

55. Firmansyah S, Penn D, Lebenthal E. Isolated colonocyte metabolism of glucose, glutamine, n-butyrate and beta-hydroxy butyrate in malnutrition. Gastroenterology 1989;97:622-9.

56. Souba WW, Scott TE, Wilmore DW. Intestinal consumption of intravenously administered fuels. JPEN 1985;9:18-22.

57. Abdulrahman AA, Ardawi SM. Glucose, glutamine and ketone-body metabolism in human enterocytes. Metabolism 1988;37:602-9.

58. Souba WW, Scott TE, Wilmore DW. Gastrointestinal regulation of parenterally administered nutrients. Surg Forum 1984;35:176-9.

59. Roediger WEW. Role of anaerobic bacteria in the metabolic welfare of the colonic mucosa in man. Gut 1980;21:793-8.

60. Weber FL, Veach GL. The importance of the small intestine in ammonium production in the fasting dog. Gastroenterology 1979;77:235-40.

61. Weber FL, Veach GL, Friedman DW. Stimulation of ammonia production from glutamine by intraluminal glucose in small intestine of dogs. Am J Physiol 1982;242:G552-7.

62. Souba WW, Wilmore DW. Postoperative alteration of arteriovenous exchange of amino acids across the gastrointestinal tract. Surgery 1983;94:342-50.

63. Souba WW, Herskowitz K, Klimberg VS, et al. The effects of sepsis and endotoxemia on gut glutamine metabolism. Ann Surg 1990;211:543-51.

64. Ardawi MAM, Jamal YS, Ashy AA,
Nasr H, Newsholme EA. Glucose and glutamine metabolism in the small intestine of septic rats. J Lab Clin Med 1990;115:660-8

65. Ardawi MSM. Glutamine and ketone-body metabolism in the gut of streptozotocin-diabetic rats. Biochem 1988;249:565-72.

66. Klimberg VS, Souba WW, Salloum RM, et al. Intestinal glutamine metabolism after massive small bowel resection. Am J Surg 1990;159:27-33.

67. Ardawi MSM, Majzoub MF Glutamine and ketone-body metabolism in the small intestine of starved peak-lactating rats. Biochimie 1988;70:749-55.

68. Ardawi MSM, Majzoub MF, Newsholme EA. Effect of glucocorticoid treatment on glucose and glutamine metabolism by the smal intestine of the rat. Clin $\mathrm{Sci}$ 1988;75:93-100.

69. Souba WW, Goldwater DL, Techtmeyer H, Mossberg K, Copeland EM III. Anabolic steroids support postoperative gut/liver amino acid metabolism. JPEN 1988;12:550-4.

70. Anderson NM, Bennett FI, Alleyne $\mathrm{GAO}$. Ammonia production by the small intestine of the rat. Biochim Biophys Acta 1976;437:238-43.

71. Budohoski L, Challis, J, Newsholme EA. Effects of starvation on the maximal activities of some glycolytic and citric acid-cycle enzymes and glutaminase in mucosa of the small intestine of the rat. Biochem J 1982;206:169-72.

72. Salloum RM, Souba WW, Klimberg VS, et al. Glutamine is superior to glutamate in supporting gut metabolism, stimulating intestinal glutaminase activity, and preventing bacterial translocation. Surg Forum 1989;40:6-8.

73. Fox A, Kripke SA, Berman BA, McGintey RM, Settle RG, Rombeau JL. Dexamethasone administration induces increased glutaminase specific activity in the jejunum and colon J Surg Res 1988;44:391-6.

74. Watford M, Smith EM, Erbelding EI. The regulation of phosphate-activated glutaminase activity and glutamine metabolism in the streptozotocin. diabetic rat. Biochem J 1984:224:207-14.

75. Ardawi MSM. The maximal activity of phosphate-dependent glutaminase and glutamine metabolism in the colon and small intestine of streptozotocindiabetic rats. Diabetologia 1987;30:109-14.

76. Salloum RM, Souba WW, Fernandez AF, Stevens B. Dietary modulation of small intestinal glutamine transport in intestinal brush border membrane 
vesicles of rats. J Surg Res

1990;48:635-8.

77. Van Voorhis K, Said HM, Ghishan

FK, Abumrad NN. Transport of

glutamine in rat intestinal brush-

border membrane vesicles. Biochim

Biophys Acta 1989;978:51-5.

8. Said HM, Van Voorhis K, Ghishan

FK, Abumurad N, Nylander W, Redha

R. Transport characteristics of

glutamine in human intestinal brush-

border membrane vesicles. Am I

Physiol 1989;256:G240-5.

9. Van Voorhis K, Said HM, Ambumrad $\mathrm{N}$, et al. Effect of chemically induced diabetes mellitus on glutamine transport in rat intestine. Gastroenterology 1990;98:862-6.

80. Brosnan JT, Man KC, Hall DE, Colbourne SA, Brosnan ME.

Interorgan metabolism of amino acids in streptozotocin-diabetic ketoacidotic rat. Am J Physiol 1983;244:E151-8.

81. Bradford N, McGivan JD. The transport of alanine and glutamine into isolated rat intestinal epithelial cells. Biochim Biophys Acta 1982;689:55-62.

82. Taylor PM, Egan CJ, Rennie MJ. Transport of glutamine across blood. facing membranes of perfused rat jejunum. Am J Physiol 1989;256:E550-8.

83. Ghishan FK, Sutter W, Said H, Leonard D, Pictsch J, Abumrad N. Gluatumine transport by rat basolateral membrane vesicles. Biochim Biophys Acta 1989;979:77-81.

84. Ardawi MSM. The transport of glutamine and alanine into rat colonocytes. Biochem J 1986;238:131-5.

85. Ghishan FK, Arab N, Said H, Pietsch J, Abumrad N. Glutamine transport by human intestinal basolateral membrane vesicle. Am J Clin Nutr 1990;51:612-6.

86. Baskerville A, Hambleton P, Benbough JE. Pathological features of glutaminase toxicity. Br J Exp Pathol 1980;61:132-8.

87. Hwang TL, O'Dwyer ST, Smith RJ, Wilmore DW. Preservation of small bowel mucosa using glutamineenriched parenteral nutrition. Surg Forum 1986;37:56-8.

88. Smith RJ, Wang XD, Wilmore DW. Glutamine enhances intestinal adaptation following massive small bowel resection Clin Res 1988;36:359A. (Abst)

89. Rombeau JL. A review of the effects of glutamine-enriched diets on experimentally induced enterocolitis. JPEN 1990;14:100S-5S.

90. Kapadia RC, Muhlbacher F, Smith RJ, Wilmore DW. Alterations in glutamine metabolism in response to operative stress and food deprivation.
Surg Forum 1982;33:19-21.

91. Miller BM, Cersosimo E, McRae J, Williams PE, Lacy WW, Abumrad NN. Interorgan relationships of alanine and glutamine during fasting in the conscious dog. J Surg Res 1983;35:310-8.

92. Ambumrad NN, Yazigi N, Cersosimo E, et al. Glutamine metabolism during starvation. JPEN 1990;14:71S-6S.

93. Heindorff H, Vilstrup H, Bucher D, Billesbolle P, Thygesen V. Increased hepatic amino nitrogen conversion after elective cholecystectomy in man. Clin Sci 1988;74:539-45.

94. Stehle P, Mertes N, Puchstein C, Zander J, Albers S, Lawin P. Effect of parenteral glutamine peptide supplements on muscle glutamine loss and nitrogen balance after major surgery. Lancet 1989;i:231-3.

95. Hammarqvist F, Wernerman J, Ali R, von der Decken A, Vinnars E. Addition of glutamine to total parenteral nutrition after elective abdominal surgery spares free glutamine in muscle, counteracts the fall in muscle protein synthesis, and improves nitrogen balance. Ann Surg 1989;209:455-61.

96. Vinnars E, Hammarquist F, von der Decken A, Wernerman J. Role of glutamine and its analogs in posttraumatic muscle protein and amino acid metabolism. JPEN 1990;104:125S-9S.

97. Souba WW, Smith RJ, Wilmore DW. Effects of glucocorticoids on glutamine metabolism in visceral organs. Metabolism 1985;34:450-6.

98. Souba WW, Kapadia SC, Smith RJ, Wilmore DW. Glucocorticoids alter amino acid metabolism in visceral organ. Surg Forum 1983;34:74-7.

99. Geer RJ, Williams PE, Lairmore T, Abumrad NN. Glucagon: An important stimulator of gut and hepatic glutamine metabolism. Surg Forum 1988;38:27-9.

100. Souba WW, Roughneen PT, Goldwater DL, Williams JC, Rowlands C. Postoperative alterations in interorgan glutamine exchange in enterectomized dogs. J Surg Res 1987;42:117-25.

101. Fong Y, Tracey KJ, Hesse DG, Albert JD, Barie PS, Lowry SF. Influence of enterectomy on peripheral tissue glutamine efflux in critically ill patients. Surgery 1990;107:321-6.

102. Souba WW, Austgen TR. Interorgan glutamine flow following surgery and infection. JPEN 1990;14:90S-3S.

103. Border JR, Hassett J, LaDuca J, et al. The gut origin septic states in blunt multiple trauma (ISS=40) in the ICU. Ann Surg 1987;206:427-48.

104. McMenamy RH, Birkhahn R, Oswald
G, et al. Multiple systems organ failure: I. The basal state. J Trauma 1981;21:99-114.

105. McMenamy RH, Birkhahn R, Oswald $\mathrm{G}$, et al. Multiple systems organ failure: II. The effect of infusion of amino acids and glucose. J Trauma 1981;21:228-36.

106. Souba WW, Strebel FR, Bull JM, Copeland EM, Teagtmeyer H, Cleary $\mathrm{K}$. Interorgan glutamine metabolism in the tumor-bearing rat. J Surg Res 1988;44:720-6.

107. Klimberg VS, Souba WW, Salloum RM, et al. Glutamine-enriched diets support muscle glutamine metabolism without simulating tumour growth. J Surg Res 1990;48:319-23.

108. Fischer JE, Chance WT. Total parenteral nutrition, glutamine, and tumor growth. JPEN 1990;14:86S-9S.

109. Heyman MB. General and specialized parenteral amino acid formulations for nutrition support. J Am Diet Assoc 1990;90:401-8,411.

110. Lo CW, Walker WA. Changes in the gastrointestinal tract during enteral or parenteral feeding. Nutr Rev 1989;47:193-8.

111. Smith RJ, Wilmore DW. Glutamine nutrition requirements. JPEN 1990; 14:94S-9S.

112. Barber AE, Jones WG II, Minei JP, et al. Composition and functional consequences of fibre and glutamine supplementation of enteral diets. Surg Forum 1989;40:15-7.

113. Barber AE, Jones WG II, Minei JP, et al. Glutamine or fibre supplementation of a defined formula diet: Impact on bacterial translocation, tissue composition, and response to endotoxin. JPEN 1990;14:335-43.

114. O'Dwyer ST, Smith RJ, Hwang TL, Wilmore DW. Maintenance of small bowel mucosa with glutamineenriched parenteral nutrition. JPEN 1989;13:579-85.

115. Grant JP, Snyder PJ. Use of L-glutamine in total parenteral nutrition. J Surg Res 1988;44:506-13.

116. Alverdy JC. Effects of glutamine-supplemented diets on immunology of the gut. JPEN 1990;14:109S-13S.

117. Burke DJ, Alverdy JC, Aoys E, Moss GS. Glutamine-supplemented total parenteral nutrition improves gut immune function. Arch Surg 1989;124:1396-9.

118. Jacobs DO, Evans DA, Mealy K, O'Dwyer ST, Smith RJ, Wilmore DW. Combined effects of glutamine and epidermal growth factor on the rat intestine. Surgery 1988;104:358-64.

119. Lowe DK, Benfell K, Smith RJ, et al. Glutamine-enriched parenteral nutrition is safe in normal humans. 
Surg Forum 1989;40:9-10.

Ziegler TR, Benfell K, Smith RJ, et al. Safety and metabolic effects of L-glutamine administration in humans. JPEN 1990;14:137S-46S.

Ziegler TR, Brown E, Smith RJ,

Ferrari-Baliviera E, Wilmore DW.

Metabolism of oral and IV glutamine in healthy humans. FASEB ]

1989;3:A1248.

Lochs H, Hubl W. Metabolic basis for selecting glutamine-containing substrates for parenteral nutrition. JPEN 1990;14:114S-7S.

Abumrad NN, Morse EL, Lochs H, Williams PE, Adibi SA. Possible sources of glutamine for parenteral nutrition: Impact on glutamine metabolism. Am J Physiol 1989;257:E228-34.

Hubl W, Druml W, Langer K, Lochs $\mathrm{H}$. Influence of molecular structure and plasma hydrolysis on the metabolism of glutamine-containing dipeptides in humans. Metabolism 1989;38(Suppl 1):59-62.

125. Magnusson I, Kihlberg R, Alvestrand A, Wernerman J, Ekman L, Wahren J. Utilization of intravenously administered $\mathrm{N}$-acetyl-L-glutamine in humans. Metabolism 1989;38 (Suppl 1):82-8.

126. Adibi SA. Intravenous use of glutamine in peptide form: Clinical applications of old and new observations. Metabolism 1989;38(Suppl 1):89-92.

127. Furst P, Albers S, Stehle P. Glutamine-containing dipeptides in parenteral nutrition. JPEN 1990;14:118S-24S.

128. Karner ], Roth E. Influence of alanylglutamine infusion on gastrointestinal glutamine and alanine metabolism in anaesthetized dogs. Metabolism 1989;38:73-7.

129. Neuhauser-Berthold M, Enfinger $H$. Utilization of intravenously administered glycyl-L-glutamine and alanyl-L-glutamine in growing rats. JPEN 1989;13(Suppl 102):215. (Abst)

130. Lochs H, Roth E, Gasic S, Hubl W, Morse EL, Adibi SA. Splanchnic, renal and muscle clearance of alanylglutamine in man and organ fluxes of alanine and glutamine when infused in free peptide forms. Metabolism 1990;39:833-6.

131. Furst P, Albers S, Stehle P. Availability of glutamine supplied intravenously as alanylglutamine. Metabolism 1990;38:67-72.

132. Furst P, Albers S, Stehle P. Evidence for a nutritional need for glutamine in catabolic patients. Kidney Int 1989;36(Suppl 27):S287-92. 


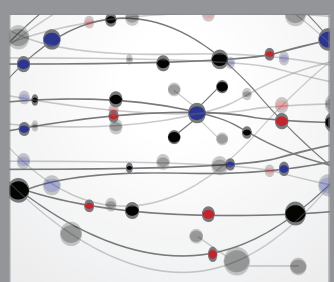

The Scientific World Journal
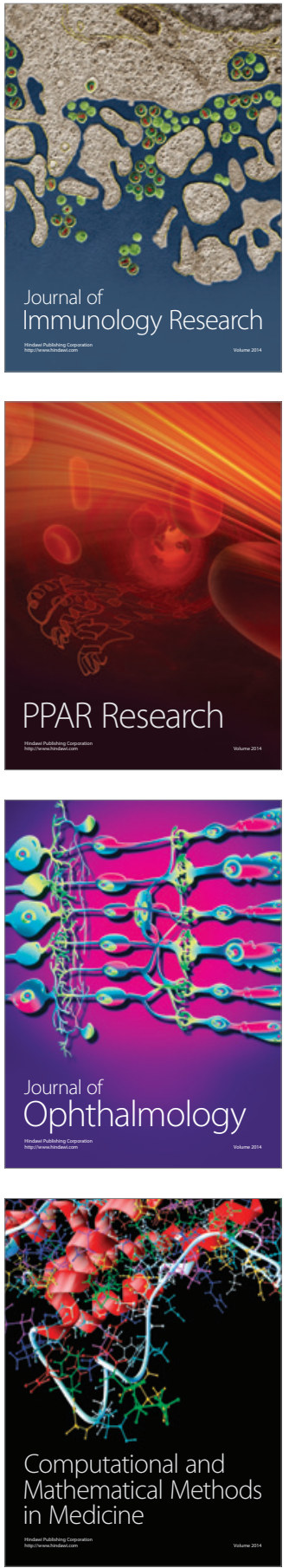

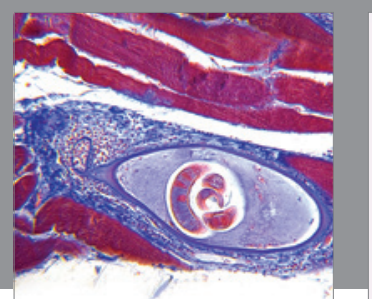

Gastroenterology Research and Practice

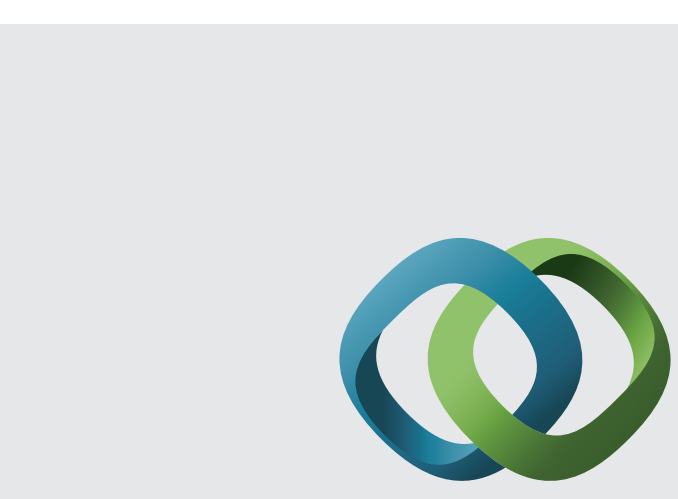

\section{Hindawi}

Submit your manuscripts at

http://www.hindawi.com
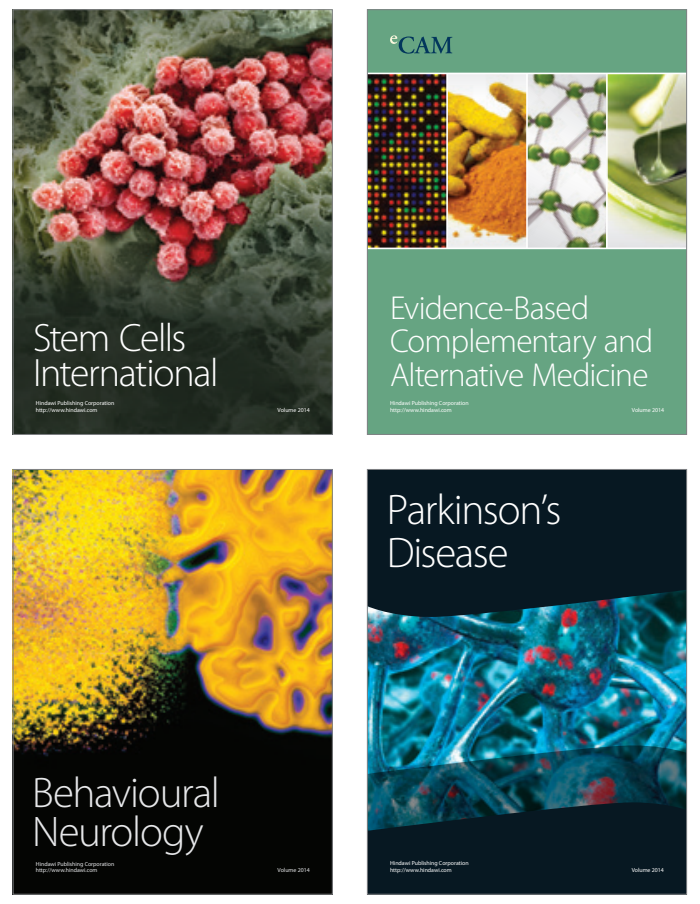
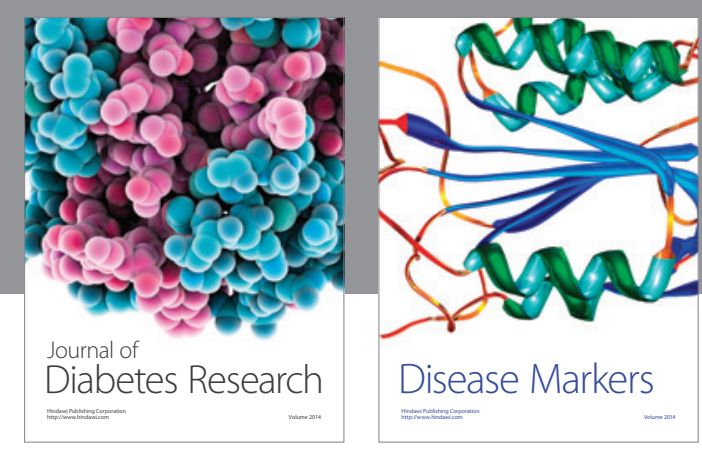

Disease Markers
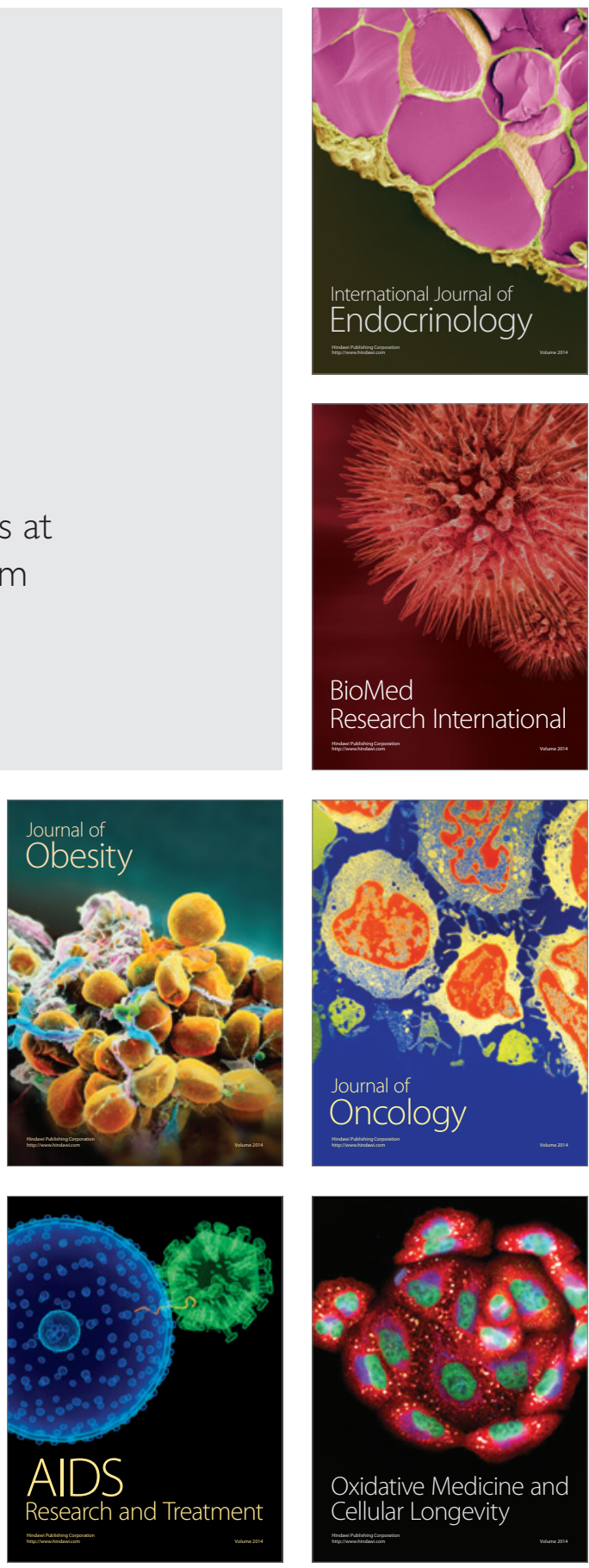